\title{
都市近郊里山で活動する市民団体の管理による木質バイオマス発生の特徴
}

\section{Characteristic of woody biomass production by citizen satoyama maintenance groups in peri-urban Tokyo}

\author{
小林昂太* 寺田 徹* 山本 博一* \\ Kouta KOBAYASHI Toru TERADA Hirokazu YAMAMOTO
}

\begin{abstract}
In Japan, most of remaining peri-urban forests have a history of being maintained as satoyama, and currently citizen volunteers are actively restoring maintenance. However, their maintenance tends to be focused on environmental conservation (e.g. biodiversity), and therefore has not be evaluated from biomass point of view, although they have been producing certain amount. This study aims to identify the characteristic of tree felling and biomass production of citizen satoyama maintenance in peri-urban areas, taking Kashiwa city, a suburban community of the Tokyo Metropolitan Region, as a case study. We conducted 'stump survey' and identified location and diameter of the over 1,137 tree stumps in 9 sites of citizen-maintained satoyama. By applying the acquired data to existing regression formulas, biomasss of elled trees were estimated. The results show that the average biomass production of citizen maintenance is $2.21 \mathrm{dt} / \mathrm{ha} \cdot \mathrm{yr}$, however, trees in isolated satoyama patches may not be regenerating as small sized trees were felled for conserving canopies. We concluded that constructing holistic biomass collection system and felling certain number of large sized trees were indispensable both for utilizing and sustaining biomass in peri-urban satoyama.
\end{abstract}

Keywords: satoyama, peri-urban areas of Tokyo Metropolitan Region, citizen forest maintenance, stump survey, sustainable biomass production

キーワード：里山, 首都圈近郊, 市民による里山管理, 切株調査, 持続的なバイオマス生産

\section{1. 背景と目的}

日本における都市近郊林の多くは，かつて農用林や薪炭林とし て維持されていた里山であるが, 経済林としての利用価值が低く, 単に放置されているものが多い。里山を含む都市近郊林の価値は, 近年では生態系サービスの点から見直されており ${ }^{1)}$, サービスの 発揮のためにも適切な管理が必要だとされている。

一方で都市近郊では, とりわけ90 年代以降, 市民団体による里 山管理が盛んに行われており，近年ではボランティア活動とプロ の林業家の中間といった高い管理能力を有する団体も現れている 2)。都市近郊里山の管理の担い手のひとりとして, こうした里山 管理団体は注目に值寸るものの，一方で，その活動範囲は限定的 だという指摘もある ${ }^{3)}$ 。都市近郊里山の管理を拡大寸るためには, たとえ市民による管理であっても, 経済林としての価值を高め, 管理の新たなインセンティブを生多出していくことが望ましいと 考えられるが，そのための手段として，近年では木質バイオマス (以下，バイオマス) のエネルギ一利用が着目される。

市民による里山管理では，間伐などを通じて一定量のバイオマ スが発生している。しかし団体の多くは管理による環境改善を目 的とするため，その副産物であるバイオマスについて，園路の 整備や木製ベンチの製造などに一部利用される以外は，十分な利 活用が図れていないと予測される。今後のバイオマス利用を推進 するためには, まずはこうした未利用材を活用することから考え, 小規模ながらもモデルとなるような取り組みを成立させ，その後 の利用拡大へ繋げていくことが妥当だと考えられる。

市民による里山管理におけるバイオマスの利用を検討するにあ たり，まずは管理によりどれだけのバイオマスが発生しているの かを明らかにする必要がある。松本ら (2011), 山場ら (2009) はこの点に着目し，里山管理付体によるバイオマス発生量を明ら かにしているが 4) 5)，いずれも 1 団体のみの調査であり, 1 年分の 発生量の夕を扱っていることから，団体の多様性やバイオマス発 生量の経年変化などが踏まえられていない。また, 既往研究では,
伐採される樹木のサイズに関する特徴については明らかにされて いないが，これを知ることは，バイオマス発生量の傾向を説明す る点と, 樹木管理の特性を知る点から, 有用な知見になり得る。

そこで本研究は，複数の里山管理闷体の調査を通じて，市民に よる里山管理における経年変化を踏まえたバイオマス発生量と, 伐採樹木サイズの特徵を明らかにすることを目的とする。得られ た結果から, 都市近郊里山におけるバイオマス利用の方向性と, そのための里山管理の方針について，議論を行う。

\section{2. 研究の方法}

\section{(1) 研究の対象}

研究対象地は都心から北東に約 $30 \mathrm{~km}$ の首都近郊に位置する千 葉県柏市とした。柏市は面積 $114.7 \mathrm{~km} \mathrm{~m}^{2}$ ，人口 416,954 人 $(2016$ 年現在）の中核市である。首都圈のベットタウンとして, 1960 年代以降開発が進み, 現在でもつくばエクスプレス沿線地域を中 心に人口が微増している。一方，平坦な台地上に約 744ha の里山 (平地林) が残存しており ${ }^{6}$, その約 9 割が落葉広葉樹林とスギ・ ヒノキ人工林によって構成される7)。

里山の多くは管理放棄され，荒廃が進行している。そのため柏 市では緑地の保全のために，市民参加による里山保全活動に対し て積極的な支援を行っている。例えば，「カシニワ制度」にもとづ き，管理が行き届かない里山を所有する地権者と，活動場所を探 している里山管理団体とを行政が仲介し, 活動協定を締結し経済 的な支援を行ったり ${ }^{8}$, 「柏市里山ボランティア入門講座」を開講 し，管理団体の養成を行ったりしている。以上のように，柏市で は, 残存する里山の管理が課題となっており, 市民による里山管 理活動の支援も充実しているため, 本研究の対象地として適切で あると判断した。

\section{(2) 調査対象団体の概要}

本研究では, カシニワ制度に登録し，地権者との活動協定を締 結した計 13 団体のうち, 調査への協力が得られた 9 団体を対象

*東京大学大学院新領域創成科学研究科 


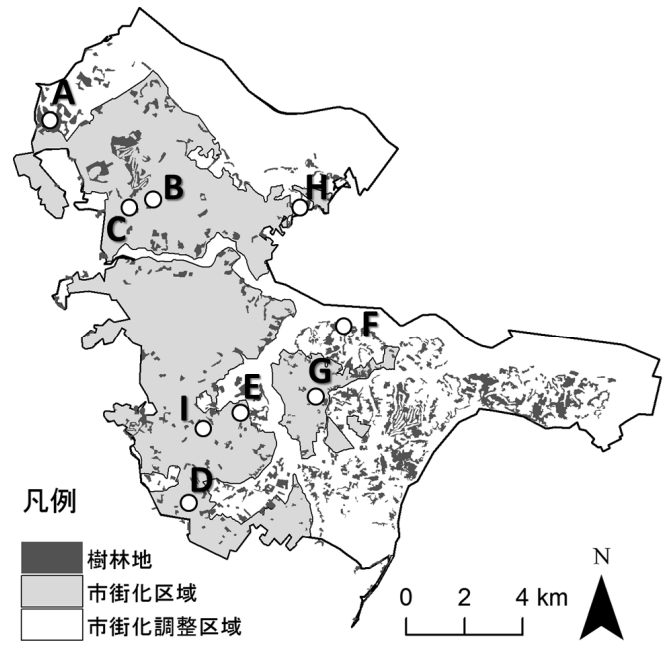

図-1 調査対象団体活動地の分布

として調查を行った。また，団体の活動地の中で，実際に伐採活 動を行い，今後もバイオマスの発生が見込める場所を調查対象地 とした。団体の活動地の分布を図ー1に, 概要を表一1に示した。 $\mathrm{A}$ を除く団体は, 2006 年から始まった柏市里山ボランティア入門 講座の入門講座の卒業生であり, 約 1 年ごとに団体が誕生してい る。多くの団体は会員数 10 人前後であり, 比較的小規模に活動し ている。また，団体の活動には主に定年退職者が参加しているた め，全体的に平均年齢が高い。団体は市街化区域もしくはその周 辺の里山で拠点を設けて活動しており,約1ha程を管理している。 団体によって異なるが，年間 40 日程管理活動を行っており，樹 木の伐採だけでなく，下草刚りや希少植物の保護，自然観察会な ど多様な活動を行っている。管理地の植生は主にスギ・ヒノキな どの針葉樹植林地に広葉樹が侵入した針広混交林が多く見られる。

\section{（3）切株調査に基づくバイオマス発生量の推定方法}

各団体の管理地からのバイオマス発生量を明らかにするため, 「切株調査」と称した調査を行った。切株調査は, 団体の管理地 内に存在する切株を立木伐採跡であるとみなし，発生量（立木状 態の地上部現存量）予測と伐採木の特徴の解明に資するため，根 元直径 $3 \mathrm{~cm}$ 以上の寸べての切株について, 根元直径, 位置, 樹種 タイプ(広葉樹と針葉樹の別) を記録するものとした。切株には, 間伐等の密度管理のために伐採した樹木と，風倒木などの処理の ために伐採した樹木が混在していると考えられるが，本研究の立 場からは，バイオマスとして利用できる材が発生したことが重要 であるため，その点からは両者の区別は必要ないと判断した。ま
た，現存する団体の管理によって発生したバイオマス量を正確に 把握するために，団体の代表者に活動開始以前から存在する切株 の有無を確認し, 存在した場合は腐食が激しい切株を活動以前に 伐採された個体と判断し，調査対象から除外した。

まず, 実測した根元直径を根元一胸高直径の関係式9)に当てはめ, 胸高直径を算定した。次に, 切株から推定した胸高直径を毎木調 查によって作成した広葉樹・針葉樹別の樹高曲線式 11 に代入し, 樹高を算出した。最後に, 推定した胸高直径と樹高を, 大香 (1991) が作成した幹材積推定式 ${ }^{12}$ に当てはめることによって翰材積を 算出し, 容積密度值 ${ }^{14}$ ， バイオマス拡大係数 ${ }^{14)}$ を掛忖合わせる ことで, 地上部バイオマスの乾燥重量 (dry-t:以下 dt) を算出し た。なお，この方法は根元直径のデータのみを実測値とした推定 であるため, 胸高直径，樹高を実測し，材積量を推定する通常の 方法と比較して精度が劣る。しかしながら, 測樹を行うにあたり 切株以外の手がかりが存在しないことから, 考えられる推定方法 の中では最も現実的であると考えた。

\section{（4）バイオマス発生量の経年変化推定}

続いて，団体ごとのバイオマス発生量の経年変化を，団体が所 有する活動記録を参照して推定した。活動記録とは，活動日ごと に，作業者数や作業内容が記録されているものを指すが，団体に より整備状況が異なっていたため, その状況に応じて，以下のよ うな方法を採用した。

活動記録が完全な状態で存在する団体 $(\mathrm{A}, \mathrm{B}, \mathrm{C}, \mathrm{E}, \mathrm{F}, \mathrm{H}$, I) については, 発足年から 2015 年度までの伐採作業日の合計と， 各年度の伐採作業日数の合計との比を算出し，その值を，それぞ れの年度における総伐採日数の相対的な配分比とした。切株調查 から推定したバイオマス発生量に対して,その值を乗じることで, 年度ごとのバイオマス発生量を推定した。一方，活動記録に伐採 作業の記録が存在しなかった団体（D）に対しては，作業内容に 最も詳しい団体メンバーに，年度ごとの伐採程度の割合を設定し てもらい，上記と同様の方法でバイオマス発生量を推定した。ま た伐採記録も存在せず，メンバーも伐採活動の程度の予測がつか なかった団体 $(\mathrm{G})$ に対しては，1 年あたりに発生するバイオマ ス量の平均值を，各年に発生するバイオマス量とした。

これらの手法は,伐採作業日数から経年変化を推定しているが, 厳密には, 当日集まった人数や会員の技量もバイオマス発生量に 影響を及ぼしていると考えられる。しかしながら，団体によって は活動記録の情報が不足している，管理技術の定量化が困難であ る等の理由から，これらを考慮するのは難しい。そのため, 本研 究目的に照らしてその傾向把握で十分と判断し，作業日数のみに よる年次配分とした。

\section{表-1 調査対象団体の概要}

\begin{tabular}{cccccccccc}
\hline 団体 & $\mathrm{A}$ & $\mathrm{B}$ & $\mathrm{C}$ & $\mathrm{D}$ & $\mathrm{E}$ & $\mathrm{F}$ & $\mathrm{G}$ & $\mathrm{H}$ & $\mathrm{I}$ \\
\hline 発足年 & 2004 & 2007 & 2008 & 2008 & 2010 & 2011 & 2013 & 2014 & 2015 \\
\hline 会員数 & 44 & 15 & 11 & 12 & 11 & 27 & 11 & 28 & 11 \\
\hline 平均年齢 & 65 歳 & 60 歳 & 65 歳 & 70 歳 & 70 歳 & 70 歳 & 67 歳 & 63 歳 & 65 歳 \\
\hline 調査地面積 & $19,000 \mathrm{~m}^{2}$ & $13,360 \mathrm{~m}^{2}$ & $7,530 \mathrm{~m}^{2}$ & $9.917 \mathrm{~m}^{2}$ & $13,347 \mathrm{~m}^{2}$ & $19,883 \mathrm{~m}^{2}$ & $5,537 \mathrm{~m}^{2}$ & $6537 \mathrm{~m}^{2}$ & $8,000 \mathrm{~m}^{2}$ \\
\hline \multirow{2}{*}{ 区域区分 } & 市街化 & 市街化 & 市街化 & 市街化 & 市街化 & 市街化 & 市街化 & 市街化 & 市街化 \\
& 調整区域 & 区域 & 区域 & 区域 & 区域 & 調整区域 & 区域 & 調整区域 & 区域 \\
\hline 年間作業回数 & 32 & 30 & 55 & 24 & 24 & 48 & 40 & 55 & 40 \\
\hline \multirow{2}{*}{ 植生 } & 広葉樹林 & 針広 & 針広 & 針広 & \multirow{2}{*}{ 広葉樹林 } & 針広 & 針広 & 針広 & 針広 \\
& 針葉樹林 & 混交林 & 混交林 & 混交林 & 林 & 混交林 & 混交林 & 混交林 \\
\hline \multirow{2}{*}{ 評価対象年数 } & $2004 \sim 15$ & $2007 \sim 15$ & $2012 \sim 15$ & $2012 \sim 15$ & $2010 \sim 15$ & $2011 \sim 15$ & $2013 \sim 15$ & $2014 \sim 15$ & 2015 \\
\hline & $(12)$ & $(9)$ & $(4)$ & $(4)$ & $(6)$ & $(5)$ & $(3)$ & $(2)$ & $(1)$ \\
\hline
\end{tabular}


表－2＼cjkstart団体毎のバイオマス発生量の概要

\begin{tabular}{cccccc}
\hline 団体 & $\begin{array}{c}\text { 切株 } \\
\text { 数 }\end{array}$ & $\begin{array}{c}\text { 総発生量 } \\
(\mathrm{dt})\end{array}$ & $\begin{array}{c}\text { 切株あたり } \\
\text { 発生量 } \\
(\mathrm{dt} / \text { 切株 })\end{array}$ & $\begin{array}{c}\text { 年平均 } \\
\text { 発生量 } \\
(\mathrm{dt})\end{array}$ & $\begin{array}{c}\text { 標準 } \\
\text { 偏差 }\end{array}$ \\
\hline $\mathrm{A}$ & 128 & 19.3 & 0.15 & 1.61 & 1.67 \\
\hline $\mathrm{B}$ & 347 & 42.7 & 0.12 & 4.74 & 2.01 \\
\hline $\mathrm{C}$ & 163 & 16.9 & 0.10 & 4.23 & 1.84 \\
\hline $\mathrm{D}$ & 87 & 11.1 & 0.13 & 2.78 & 0.82 \\
\hline $\mathrm{E}$ & 24 & 2.35 & 0.10 & 0.39 & 0.44 \\
\hline $\mathrm{F}$ & 285 & 23.8 & 0.08 & 4.76 & 1.51 \\
\hline $\mathrm{G}$ & 81 & 10.4 & 0.13 & 3.47 & 0 \\
\hline $\mathrm{H}$ & 16 & 3.93 & 0.25 & 1.97 & 0.3 \\
\hline $\mathrm{I}$ & 6 & 0.11 & 0.02 & 0.11 & 0 \\
\hline 計 & 1,137 & 130.4 & - & - & - \\
\hline 平均 & 126 & 14.45 & 0.12 & 2.67 & 0.97 \\
\hline
\end{tabular}

\section{3. 結果と考察}

\section{（1）切株調査に基づくバイオマス発生量の推定値}

切株調査に基づく9団体におけるバイオマス発生量の推定值を, 表一 1 に示した。切株の総数は 1,137 個体であり，これまでの累 積で約 130dt のバイオマスが発生していたと推定された。切株あ たりの発生量の平均值は $0.12 \mathrm{dt}$ であるため, 平均的には, 地上部 の乾燥重量が $120 \mathrm{~kg}$ 程度の樹木を伐採し, バイオマスが発生して いることになる。切株あたりの発生量は, 団体 A〜Gにおいては 平均值との差が少なく, 近年設立された団体 $\mathrm{H}$ およびIにおいて 大きい。団体への聞き取り調査によれば，団体 Hについては，林 内に広場的空間を確保するため, 樹冠の大きい大径木を優先的に 伐採したという経緯があり，このことが，高い切株あたり発生量 の要因だと考えられる。一方団体 I は, 対象団体のうち最も新し い団体であり, 現段階では下草刚りを中心とする整備が主であり, 樹木の伐採は控えているため, 低い值を示したものと考えられる。 また, 団体ごとの評価対象年数の值を用いて, 年平均発生量を算 出したところ，0.11～4.76dt（平均 2.67dt）となった。

\section{（2）バイオマス発生量の経年変化}

このことに関連して, 図-2 には, 各団体のバイオマス発生量 の経年変化と，9 団体の発生量を合計した值を示した。これをみ ると，団体ごとのバイオマス発生量は安定しておらず，それぞれ ばらついていた。活動地の植生状態や管理方針，技術力は団体に よって多様であるため, 経年変化に共通の傾向を見出すことは困 難と考えられる。

図一2 中の 9 団体のバイオマス発生量の合計值の経年変化をみ ると, 2012 年までは団体数の増加とともに発生量も増加している が，それ以降は 20dtで推移していた。これはバイオマスの発生 が減少傾向に転じている団体がある一方，新たな団体が一定量の バイオマスを生産しており，その増減を相殺しているためと考え

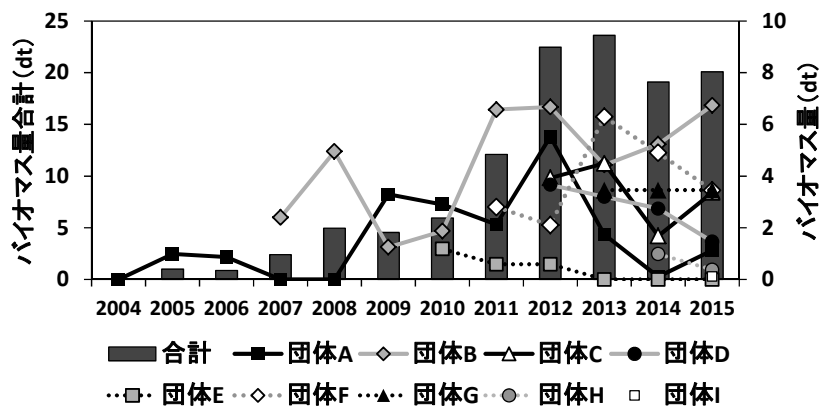

図一2 バイオマス発生量の経年変化

られる。新たな団体は今後バイオマス発生が期待されるため，今 後数年間, 団体数や団体の状態が変化しないという条件下におい ては，概ね年間 20dt 程度で推移すると予想される。

（3）ha あたりバイオマス発生量

図一3の左には，各団体間の比較を行うため，バイオマス発生 量を単位面積（ha）あたりの值に換算し，最大值，最小值，平均 值を示した。団体間のばらつき，同一団体の異なる年次における ばらつきがともに大きく，里山の状態や管理の方針により，発生 量が多様であることが分かる。図一 4 には，各団体の管理地にお いて確認された切株直径別におけるバイオマス量と切株本数を示 した。また，伐採への積極性を表す指標として，haあたり年間伐 採本数（二切株本数）も表記した。このデータと図-3 (左) の データを比較すると, 発生量の少ない団体 A, E, H, Iにて年間 伐採本数が低く, 多い団体 B， C, D , F , G では年間伐採本数が 高く，概ね対応していることが分かる。ただし，団体 C は年間伐 採本数は最も高いものの, バイオマス発生量は団体 $\mathrm{G}$ のほうが多 いなど，一部例外がある。これは，団体 C は，根元直径 $50 \mathrm{~cm}$ 以 上の大径木の伐採数が他の径の樹木に比へてて相対的に少ないこと に対して, 団体 Gでは大径木の本数が多く, このことが影響して いると考えられる。この点について，大径木の伐採が目立つ団体 G およびDへのヒアリングによれば, 管理地が住宅地と接してお り，近隣住民が落葉の蓄積や日陰を嫌ったことから，住宅に近い
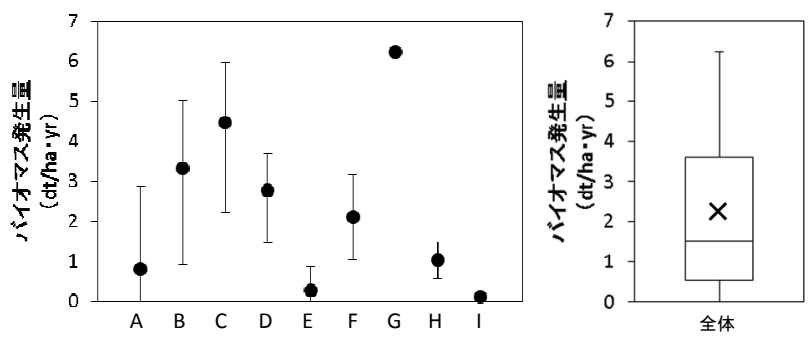

図一～団体別ha あたりバイオマス発生量（左）と 全団体の全評価年における発生量（右）

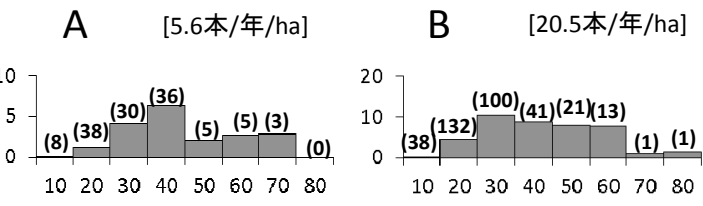
C $[54.1$ 本/年/ha]

D

[21.9本/年/ha]
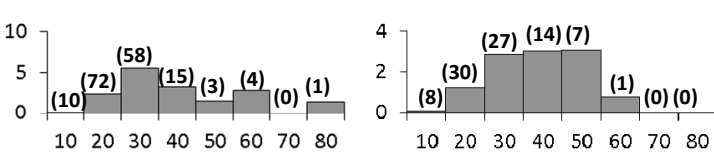

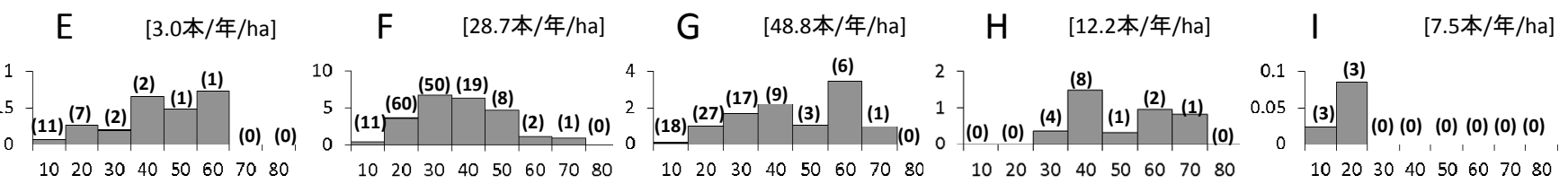

図一4 根元直径階別のバイオマス量（縦軸の単位は $\mathrm{dt}$ ，横軸は $\mathrm{cm} 。 （ ）$ 内の数字は切株本数を示す） 
範囲の大径木の処理の依頼を受けたという事情が聞かれた。一方, 本数を見ると全体として根元直径 $10 \sim 30 \mathrm{~cm}$ 程度の小中径木に伐 採木が偏っている。各団体へのヒアリングによれば, これは伐採 が容易である，樹冠を構成している大径木をなるべく残したいと いう 2 つ理由にもとづくものであることが分かった。

最後に, 図一 3 の右に，全寺体，全評価年の単位面積当たりバ イオマス発生量 $(n=46)$ のデータを, 箱ひげ図の形で整理した ところ, 平均值は $2.21 \mathrm{dt} / \mathrm{ha} \cdot \mathrm{yr}$ となった。ただし標準偏差を計 算すると 1.97 となり，ばらつきが大きかった。

\section{4. 研究のまとめおよび今後の展望}

本研究で得られた知見は以下の 3 点にまとめられる。

- 千葉県柏市の都市近郊里山を対象として, 市民による里山管 理におけるバイオマス発生量を, 切株調査に基づき推定した ところ，9 団体の活動により，年間 $20 \mathrm{dt}$ 程度のバイオマス が発生していると見積もられた

- 今回対象とした市民による里山管理では, 伐採の容易さと, 林冠を構成する高木は残したいという意向から, 概して根元 直径 10〜 30cm 程度の小中径木の伐採が目立っていた

・ ha あたり年間発生量の平均值は $2.21 \mathrm{dt} / \mathrm{ha} \cdot \mathrm{yr}$ となったが, 団体ごと, 年次ごとのばらつきが大きい。ばらつきの主な要 因は, 伐採速度の違い及び大径木処理の 2 点から説明できた 既往研究では, 里山のバイオマス発生量について, 仮に管理を 行う場合の発生量を予測する等，ポテンシャルの推定に関するも のが多かったが，本研究では，切株調査により，実際に利用可能 なバイオマス発生量を推定することが出来た。20dt/yr という数 值は，柏市付近（我孫子市）の気温に基づき推定された 1 世帯当 たり年間薪消費量 $(1.88 \mathrm{dt} / \mathrm{yr})$ 15) に対しては約 10 台分となる。 こうした数值は, 今後, 里山のバイオマス発生量とバランスする 薪ストーブやペレットストーブといった熱需要の創出を考えるに あたり，参考となる。

市民による里山管理活動を持続的なものにするためには, 活動 に対するモチベーションを持続させることが重要である。バイオ マスの販売による収益の獲得は，多くの団体でこれまでにはない 新たなモチベーションとなると考えられる。一方で，20dt/yr と いう值は，市内におけるバイオマス利用を考えていく上で微少だ と言わざるをえず，コストバランスを考慮すると，各団体からバ イオマスを収集して利用を推進していくことは難しい。従って, 都市近郊の特性を生かし，例えば近隣の住宅の庭や都市公園の管 理によって発生する剪定枝などと合わせてさらなる量のバイオマ スを確保するなど，より現実的なバイオマス利用の方策を検討す る必要があるだろう。

本研究で対象とした里山管理団体は, 例外的に大径木も処理し てはいるが，基本的に小中径木の伐採を行っていることから，高 木を残し，林内に広がりをつくるような立木管理を行っていると 予想される。こうした管理によって維持される林は, 中川 (2004) が「環境高林」と呼ぶように，目標とする林相のひとつの典型で ある 17)。しかしながら, 将来の林冠構成種となる中低木が失われ ていること，残った高木は高齢化し，健全度の低下や風倒のリス クが高まることなど, デメリットも指摘できる ${ }^{18)}$ 。エネルギーと して利用できる一定量のバイオマスを得ること，および後継樹を 育て, 将来のバイオマスストックを確保することの 2 点からは, 高木を徐々に伐採することも必要であると言える。その一方，大 径木の伐採は市民による管理では難度が高いため, 森林組合等職 業的技術者による支援も必要だと考えられる。

本研究の解析は, 首都圏の平地林を対象としたものであるが, 地形・植生条件等によりバイオマス発生の傾向は異なると考えら れるため, 推定值の適用範用が限られている。議論を充実させる
ためには，同様の調査を別の地域でも行い，より多くの知見を得 ることが必要である。また, 本研究では新たに切株調査を発案し, バイオマス発生量の経年変化を推定したが，今回算出した值の正 確性を検証するためには，里山活動団体による樹木伐採のモ二タ リングを行うなどして，実際に発生したバイオマス量との比較が 必要であろう。今後の重要な研究課題としたい。

謝辞

本研究を進めるにあたり, 調査にご協力頂いた里山管理団体の 皆様，柏市公園緑政課の渡邊様と内埜様をはじめ、多くの皆様に 大変お世話になりました。ここに記して謝辞とさせて頂きます。

\section{補注及び引用文献}

1）奥敬一(2013)：里山林の生態系サービスを発揮するための課題と農 村計画の役割：農村計画学会誌 32(1)，20-23

2）寺田徹・横張真・ボルトハウス ジェイ・松本類志 (2010) : 都市近郊 での森林施業計画に基づく市民による里山管理活動の実態 : 農村計画 学会誌 $29,179-184$

3）恒川篤史 (2002) : 里地自然を保全するための長期的戦略 : 武内和彦・ 熟谷いら゙み・恒川篤史 (編)「里山の環境学」: 東京大学出版会, 204-218

4） 松本類志・横張真・寺田徹・山本博一 (2011) : 都市近郊里山におけ る市民の管理にもとづく木質バイオマス発生量の推定 : ランドスケー プ研究 74(5), 707-710

5）山場淳史・渡邊園子・齋藤一郎・中越信和（2009）：ボランティア団 体による木質バイオマス活用を目的としたマツ林型里山保全活動を支 援するための技術的検討と合意形成過程：景観生態学 14(1)，73-81

6) 千葉県森林課 (2012): 千葉北部地域森林計画書 $<$ https://www.pref.chi ba.lg.jp/shinrin/keikaku/nourinsuisan/shinrinkeikaku.html>, 201 6. 9.19 参照

7）環境省(1999）：第5 回自然環境保全基礎調査：<www.biodic.go.jp/ki so/vg/vg_kiso.html>2015. 5. 10 参照

8）細江まゆみ(2016)：カシニワ制度の効果に関する一考察 $<\mathrm{https://ww}$ w.hosei.ac.jp/toukei/shuppan/g_shoho47-hosoe.pdf $>, 2016.9 .20$ 参 照

9）広葉樹は（y=0.735x）を使用。針葉樹はスギ・ヒノキの元データか ら針葉樹における根元-胸高直径の関係式を作成し, 式 $(\mathrm{y}=0.6784 \mathrm{x})$ を得た ${ }^{9)}$

10）日本リサイクル緑化協会(1998)：根株の容積及び重量の推定につい $\tau<$ http://www.japan-recycle.com/>, 2016.9.20 参照

11）広葉樹（ $\mathrm{y}=7.2383 \ln (\mathrm{x})-4.9018 ）$ 針葉樹（ $\mathrm{y}=6.5597 \ln (\mathrm{x})-4.1$ 922）を使用。毎木調查は柏市の植生を代表していると考えられる場 所で行った

12）幹材積 $\mathrm{y}=0.05672\left(\mathrm{DBH}^{2} \mathrm{H}\right)^{0.9506 / 1000}$ 12) を使用

13）大香誠一 (1991) : 森林の現存量推定法の検討 : 伐倒によらない推定 法: 京都大学農学部演習林報告 (1991) 63, 23-36

14）温室効果ガスインベントリオフィス (2015) : 日本国温室効果ガスイ ンベントリ報告書 : 国立環境研究所, 6-12

15) 月平均最低気温 $\mathrm{x}\left({ }^{\circ} \mathrm{C}\right)$ と薪消費量 $\mathrm{y}$ の関係式 $(\mathrm{y}=50.854 \mathrm{x}+492.22)$ 13) を使用

16）東京大学(2015）: 明るい低炭素社会の実現に向けた都市変革プログ ラム最終報告書 $<$ http://low-carbon.k.u-tokyo.ac.jp/index.html > , 2 016. 9.20 参照

17）中川重年(2004) : 森づくりテキストブックー市民による里山林・人工 林管理マニュアル : 山と渓谷社, 223

18）森林総合研究所(2010) : 里山に入る前に考えることー行政およびボラ ンティア等による整備活動のために-<http://www.ffpri.affrc.go.jp/fs m/research/pubs/documents/satoyama3_201002.pdf $>$, 2016. 12.6 参照 